UDC 637.521+639.38] - 053.9

DOI https://doi.org/10.37734/2518-7171-2021-1-3

\title{
DEVELOPMENT OF NEW TYPES OF MEAT AND FISH SEMI-FINISHED PRODUCTS OF HERODIETIC NUTRITION
}

\author{
L. V. PESHUK, Doctor of Agricultural Sciences, Professor \\ (Oles Honchar Dnipro National University);
}

G. V. NOVIK, Candidate of Technical Sciences

(Oles Honchar Dnipro National University);

\begin{abstract}
A. M. SAVCHENKO (Oles Honchar Dnipro National University);
I. P. GONCHARENKO (Oles Honchar Dnipro National University)
\end{abstract}

\begin{abstract}
Health is a unique value of humanity, especially in the global era of the COVID-19 pandemic, so improving the health of the population is the main task of a society that strives for prosperity and sustainable development. The food industry is critical to humanity and the planet. The question of the expediency of a balanced diet to ensure the quality and prolong the duration of socially active life is becoming increasingly important in almost all countries of the world. The creation of new food is due to many factors: global climate change, leading to certain problems in crop and livestock, the general deterioration of human health associated with new technologies for growing, processing and production of food, which is a prerequisite for inventing preventive or curative food and beverages. The meat industry, as the most important branch of the national economy, provides the country's population with one of the main sources of protein. With its multi-vector development, one of the important directions is the production of frozen products, including meat and meat-containing cut semi-finished products. Despite the unstable economic situation in the country and low purchasing power of the population, especially the elderly, among the main factors shaping the dynamics of this segment is the deepening of intersectoral cooperation, namely in the meat industry - expanding the range of frozen semi-finished products.

Given the above, a timely and promising direction is the development of recipes and improving the technology of production of meat and fish semi-finished products using meat (turkey fillet), fish (hake), vegetable raw materials and blends of oils (high oleic sunflower and grape seed oils). According to the results of research, recipes were developed and the nutritional value of the new product was calculated.
\end{abstract}

Key words: meat and fish semi-finished product, blend of oils, herodietic nutrition, nutritional value.

Statement of the problem in general. The issue of preserving and improving the health of the country's population is a priority of the state [1]. In many developed countries, the proportion of the elderly is about $20-25 \%$. According to UN forecasts, the percentage of people in this age group will almost double over the next 50 years. By 2050, the number of people over the age of 60 in the EU is expected to increase to $38.1 \%$. This forecast can be explained primarily by declining birth rates and total population in the vast majority of regions [2]. This means that more than a third of the population will need special care, treatment, prevention of pathologies of various etiologies, including the organization of nutrition, which significantly affects the general condition of the human body and life expectancy [3].

Analysis of recent research and publications. Research in the field of implementing effective measures to increase the creative longevity of the population, preserve its health and prevent disease is relevant and has social, economic and political significance [4]. For a large part of the elderly population, the most important factor in healthy old age is a balanced diet [5]. With this in mind, many scientists from different countries are working to expand the range of functional foods that contain ingredients that increase the human body's resistance to disease, allowing it to lead an active lifestyle for a long time [6].

There are currently no meat and fish products for the elderly in the retail chain [7]. Products using only one type of meat or fish raw materials represent the range of chopped semi-finished products $[8,9]$. Scientists in many countries pay considerable attention to the development of new (innovative) products, balanced in composition, which would be included in the daily diet and provide a positive impact on the body of the elderly. Thus, taking into account both theoretical and practical works of scientists, additional research is needed on technologies for the production of multicomponent meat products, including studying the impact of certain ingredients on improving biological efficiency, improving physicochemical and organoleptic characteristics of meat and fish semi-finished products [10].

Despite numerous studies on the creation of products with high nutritional and biological value, the range of the last is small. They mainly involved a combination of different types of meat and vegetable raw materials, the introduction of mineral and protein supplements, iodine-containing raw materials [11]. Combining raw meat and fish in different proportions in the technology of production of semi-finished 
products for functional purposes is an important area of research in view of the development of this type of semi-finished product today.

Forming of the article goals. The aim of the work is to develop new types of meat and fish products, which contain an innovative component in the form of functional ingredients with a high degree of digestibility, high biological and nutritional value.

Statement of the main research material.

Samples of meat and fish semi-finished products were the objects of research:

- meat semi-finished product - "Chopped poultry cutlets" (control) [12];

- fish semi-finished product - "Fish cutlets" (control 2) [12];

- three recipes of semi-finished products with replacement of turkey fillet in the amount of $20 \%$, $24 \%$ and $28 \%$ for fish fillet were developed.

Nutritional value was determined by calculation using data taken from the reference literature on the composition of raw materials [13].

Amino acid score was calculated by a well-known method for an ideal protein [14].

Also we evaluated the quality of products during storage according to their microbiological contamination in accordance with GOST 30518 [14], the presence of pathogenic microorganisms, including Salmonella in $25 \mathrm{~g}$ and pathogenic staphylococcus in $1 \mathrm{~g}$ according to GOST 26972 [15], the amount of yeast micromycetes in $1 \mathrm{~g}$ in accordance with DSTU 8447 [16].

For the development of herodietic meat and fish semi-finished products, turkey meat with a tender texture, juiciness and aroma was chosen; among fish raw materials - hake fillets as the most available raw material for people of this age category. For greater tenderness, juiciness and improvement of the taste of meat and fish cutlets and harmonization of the fatty acid composition of the finished product, a blend of oils was introduced into the recipe of meat and fish semi-finished products: high-oleic sunflower (according to DSTU 4492: 2005) and grape seed oils (TU U 15.4-25399227-008: 2007 "Refined and unrefined packaged edible oils. Specifications") in the ratio of 70:30.

During the study, recipes for meat and fish semi-finished products with different ratios of meat and fish raw materials and technology of their preparation were developed. Samples were prepared according to the classical technology with partial replacement of raw meat (turkey fillet) with fish (hake) in the ratio shown below (tabl. 1), grape seed oil and high oleic sunflower oil were added to the developed samples at the mixing stage. According to the results of sensory analysis of finished products, three recipes of meat and fish semi-finished products were selected (tabl. 1) for further research.

Given that the purpose of the study is to develop meat and fish products, we consider it appropriate to compare the chemical composition of some indicators of meat and fish raw materials as the main recipe components of new products.

The nutritional value of protein products depends on the amino acid composition of proteins, in particular the presence of essential amino acids (tabl. 3). In the course of calculations of amino acid scores, data on the amino acid composition of egg white (based on information sources) were used.

It was noted (tabl. 2) that the proteins of experimental samples 4 in comparison with proteins of control 1 and 2 have a better amino acid score for tryptophan (1,1 times). The amino acid score for other amino acids of test samples 4 and 5 compared to control 1 is higher by $1,2 \ldots 1,5$ times, but approximately at the same level as control 2.

Table 1

Recipe composition of meat and fish semi-finished products

\begin{tabular}{|l|c|c|c|c|c|}
\hline \multirow{2}{*}{ Raw materials } & \multicolumn{5}{c|}{ Mass of raw materials, } \\
\cline { 2 - 6 } & Control 1 & Control 2 & Sample 3 & Sample 4 & Sample 5 \\
\hline Turkey fillet & 65,7 & - & 33,8 & 42,6 & 48,2 \\
\hline Hake & - & 70,2 & 28 & 24 & 20 \\
\hline Melange & - & - & 9,8 & 9,8 & 9,8 \\
\hline Sunflower oil & - & - & 4,5 & 4,5 & 4,5 \\
\hline Grape seed oil & - & - & 1,9 & 1,9 & 1,9 \\
\hline Wheat bread & 12,0 & 12,0 & - & - & - \\
\hline Flour: & - & - & 9,7 & - & - \\
wheat & - & - & - & 4,9 & - \\
\hline rice & - & - & - & - & 3,3 \\
\hline oat & 11 & 11 & 11 & 11 & 11 \\
\hline Onion & 1,1 & 1,1 & 1,1 & 1,1 & 1,1 \\
\hline Kitchen salt & 0,2 & 0,2 & 0,2 & 0,2 & 0,2 \\
\hline Ground black pepper & 10,0 & 5,5 & - & - & - \\
\hline Water & 100 & 100 & 100 & & 100 \\
\hline Total: & & & - & 100 \\
\hline
\end{tabular}


Table 2

Amino acid rate of meat and fish semi-finished products

\begin{tabular}{|l|c|c|c|c|c|}
\hline \multirow{2}{*}{ Amino acid } & \multicolumn{5}{|c|}{ Amino acid rate of meat and fish semi-finished product, \% } \\
\cline { 2 - 5 } & Control 1 & Control 2 & Sample 3 & Sample 4 & Sample 5 \\
\hline Valine & 71 & 104 & 83 & 85 & 84 \\
\hline Isoleucine & 77 & 114 & 91 & 91 & 91 \\
\hline Leucine & 101 & 115 & 106 & 107 & 107 \\
\hline Lysine & 148 & 160 & 146 & 152 & 151 \\
\hline Methionine + cystine & 98 & 108 & 109 & 110 & 109 \\
\hline Threonine & 92 & 105 & 96 & 97 & 99 \\
\hline Tryptophan & 105 & 108 & 113 & 115 & 109 \\
\hline Phenylalanine + tyrosine & 111 & 124 & 115 & 115 & 116 \\
\hline
\end{tabular}

Table 3

Assessment of compliance of fatty acid composition of lipids of meat and fish semi-finished products with the recommended norms of their consumption

\begin{tabular}{|c|c|c|c|c|c|c|}
\hline \multirow{2}{*}{ Fatty acid } & \multicolumn{5}{|c|}{ Fatty acid content, g / $100 \mathrm{~g}$ of product } & \multirow{2}{*}{$\begin{array}{l}\text { Recommended } \\
\text { amount, g/day }\end{array}$} \\
\hline & Control 1 & Control 2 & Sample 3 & Sample 4 & Sample 5 & \\
\hline Saturated, including & $\mathbf{0 , 3}$ & $\mathbf{0 , 5}$ & 1,33 & 1,36 & 1,62 & 25 \\
\hline Myristic $\left(\mathrm{C}_{14: 0}\right)$ & 0,007 & 0,06 & 0,03 & 0,03 & 0,02 & \\
\hline Palmitine $\left(\mathrm{C}_{16: 0}\right)$ & 0,21 & 0,31 & 0,24 & 0,2 & 0,196 & \\
\hline Stearic $\left(\mathrm{C}_{18: 0}\right)$ & 0,07 & 0,12 & 0,09 & 0,07 & 0,066 & \\
\hline Monounsaturated, including & 0,39 & 0,48 & 2,39 & 2,49 & 2,35 & 30 \\
\hline Palmitoleic $\left(\mathrm{C}_{16: 1}\right)$ & 0,05 & 0,1 & 0,08 & 0,07 & 0,076 & \\
\hline Oleic $\left(\mathrm{C}_{18: 1}\right)$ & 0,33 & 0,3 & 0,30 & 0,25 & 0,264 & \\
\hline Gadoleic & 0,001 & 0,07 & 0,03 & 0,026 & 0,022 & \\
\hline Polyunsaturated, including & $\mathbf{0 , 3 9}$ & $\mathbf{0 , 5 1}$ & 4,42 & 4,49 & 4,24 & 11 \\
\hline Linoleic $\left(\mathrm{C}_{18: 2}\right) \omega 6$ & 0,35 & 0,20 & 4,28 & 4,13 & 4,14 & \\
\hline Linolenic $\left(\mathrm{C}_{18: 3}\right) \omega 3$ & 0,03 & 0,30 & 0,14 & 0,12 & 0,10 & \\
\hline Arachidonic & 0,013 & 0,014 & 0,01 & 0,013 & 0,013 & \\
\hline
\end{tabular}

The content of valine, isoleucine, leucine is approximately 1: 1: 1 protein, which corresponds to the recommended daily intake of man. A slight increase in the ratio of lysine and tryptophan was found, which indicates improved absorption of calcium and blocking the excretion of trace elements.

The biological efficiency of lipids of developed meat and fish semi-finished products was determined by their fatty acid composition (tabl. 3). Blending of oils is the most effective and economically justified method of designing fatty products with a given composition and ratio of PUFA, which corresponds to the basics of nutrition science.

The content of unsaturated fats in the developed meat and fish products of samples 3 and 4 is $20 \%$ of the total fat, and in sample 5-24\%. The dominant fraction among PUFAs in all samples is essential linoleic acid, the content of which in the experimental samples of meat and fish semi-finished products is almost at the same level, while in control samples 1 and 2 the acid content is lower by $11 \%$ and $10 \%$ respectively.

The main representative of MUFAs is oleic; its content in the studied samples varies within 30\%, which in comparison with control 1 and 2 remains at the appropriate level in the developed samples. Among the SFA in control 1 and 2, palmitic acid predominates, which is slightly lower in the studied samples than in the control ones.

Indispensable nutrients in a person's diet are non-synthesized in his body vitamins that should be regularly supplied in quantities that meet physiological needs.

The developed meat and fish semi-finished products are characterized by a high content of vitamin $\mathrm{E}$ $(2,6-2,32 \mathrm{mg} / 100 \mathrm{~g}$ in the experimental samples) due to the use in the prescription composition of a significant amount of blended oils.

In all experimental samples found a significant content of vitamin $B_{4}: 75,21$ and $74,34 \mathrm{mg} / 100 \mathrm{~g}-$ samples 4 and 5, which is much more than in the control $-43,25$ and $56,13 \mathrm{mg} / 100 \mathrm{~g}$ of product, respectively. In addition, the developed meat and fish semi-finished products have a high content of nicotinic acid and vitamin $B_{12}$. The use of these semi-finished products provides a daily requirement of vitamin $\mathrm{B}_{6}$ by an average of $22,6 \%, \mathrm{~B}_{12}-$ by $36,3 \%$, E - by about $10,4 \%$, nicotinic acid - by $25 \%$.

We determined the quality and safety of meat and fish semi-finished products on microbiological 
indicators. The study of microbiological parameters of frozen meat and fish semi-finished products during storage showed that the indicators of E. coli (coliforms), opportunistic and pathogenic microflora are within acceptable values (tabl. 4).

The amount of MAFANM in the experimental samples underwent minor changes, but after six weeks did not exceed the allowable level during storage at a temperature of minus $18^{\circ} \mathrm{C}$. Since, there is no normative documentation for meat and fish semi-finished products in Ukraine, we were guided by the norms established for meat chopped semi-finished products, namely DSTU 4437: 2005 "Semi-finished meat and meat and vegetable chopped products. Specifications", according to which the shelf life at a temperature of minus $18^{\circ} \mathrm{C}$ is not more than 60 days. The duration of storage of the developed meat and fish semi-finished product is 42 days (research period). Meat and fish semi-finished products belong to the culinary frozen products, which have a limited shelf life, during which there are changes in the complex of organoleptic, physicochemical and microbiological parameters. Changes in quality indicators were recorded during storage of semi-finished products in the refrigerator at a temperature of minus $18^{\circ} \mathrm{C}$ for six weeks (study period).

In the study of changes in organoleptic quality indicators of meat and fish semi-finished products, their highest level was recorded during the first seven days. The overall evaluation of the products after the seventh day with increasing storage period gradually decreased.

During 42 days of storage, all three developed samples of semi-finished products were characterized by uniform color - from white to light gray. The smell of meat and fish semi-finished products, made according to recipes $3-5$, is described as pleasant, characteristic of this type of product.
No foreign odors, odor of fat oxidation during the entire storage period. The consistency of the test samples is homogeneous, without lumps, foreign inclusions, without stratification of the consistency. The taste of meat and fish semi-finished products is typical of this type of product, without any foreign taste.

The study of changes in moisture content showed that after six weeks of storage, the mass fraction of moisture in control sample 2 decreased by $3 \%$, in control sample 1 and all experimental - by $2.5 \%$.

The purpose of the cost calculation is to determine the difference in the cost of raw materials for control and meat-fish samples. Their comparative assessment is proposed below (fig. 1).

Analyzing the obtained data (fig. 1), it should be noted that the cost price (CP) of raw materials of developed meat and fish products is slightly lower than the CP of raw materials of control sample 1 (turkey fillet). It can be noted that fish products are not popular among the majority of the population, so the combination is a decisive factor in the case of their consumption, and because of price comparison, the developed samples were cheaper than the control sample 1 .

Conclusions from these problems and prospects for further research in this area. Based on the analysis of theoretical and experimental research, the technology of production of meat and fish semi-finished products for heroic nutrition has been improved by combining turkey and fish (hake) fillets, vegetable raw materials and blends of vegetable oils.

It is proved that higher indicators of biological value of proteins and lipids characterize the developed semi-finished products. The proposed meat and fish semi-finished products have better organoleptic characteristics, higher content of vitamins E and B group compared to control samples.

Table 4

Changes in microbiological parameters of meat and fish semi-finished products during refrigerated storage

\begin{tabular}{|c|c|c|c|c|c|c|c|}
\hline Indicator & $\begin{array}{c}\text { Duration } \\
\text { of storage, } \\
\text { days }\end{array}$ & Control 1 & Control 2 & Sample 3 & Sample 4 & Sample 5 & Valid level \\
\hline \multirow{4}{*}{$\begin{array}{l}\text { MAFANM, } \\
\text { CFU / g }\end{array}$} & 1 & $2,4 \times 10^{3}$ & $2,1 \times 10^{4}$ & $2,0 \times 10^{3}$ & $2,0 \times 10^{3}$ & $2,0 \times 10^{3}$ & \multirow{4}{*}{$\begin{array}{c}\text { Not more than } \\
1,0 \times 10^{6}\end{array}$} \\
\hline & 14 & $2,7 \times 10^{3}$ & $3,1 \times 10^{4}$ & $2,5 \times 10^{3}$ & $2,4 \times 10^{3}$ & $2,4 \times 10^{3}$ & \\
\hline & 28 & $3,5 \times 10^{4}$ & $4,0 \times 10^{5}$ & $3,0 \times 10^{4}$ & $2,8 \times 10^{4}$ & $2,7 \times 10^{4}$ & \\
\hline & 42 & $3,8 \times 10^{4}$ & $4,5 \times 10^{5}$ & $3,3 \times 10^{4}$ & $3,0 \times 10^{4}$ & $3,0 \times 10^{4}$ & \\
\hline E. coli in $0,1 \mathrm{~g}$ & $1-42$ & $\begin{array}{c}\text { Not } \\
\text { detected }\end{array}$ & $\begin{array}{c}\text { Not } \\
\text { detected }\end{array}$ & $\begin{array}{c}\text { Not } \\
\text { detected }\end{array}$ & $\begin{array}{c}\text { Not } \\
\text { detected }\end{array}$ & Not detected & Not allowed \\
\hline S. aureus in $0,1 \mathrm{~g}$ & $1-42$ & $\begin{array}{c}\text { Not } \\
\text { detected }\end{array}$ & $\begin{array}{c}\text { Not } \\
\text { detected }\end{array}$ & $\begin{array}{c}\text { Not } \\
\text { detected }\end{array}$ & $\begin{array}{c}\text { Not } \\
\text { detected }\end{array}$ & Not detected & Not allowed \\
\hline $\begin{array}{l}\text { Pathogenic, } \\
\text { including } \\
\text { Salmonella in } 25 \mathrm{~g}\end{array}$ & $1-42$ & $\begin{array}{c}\text { Not } \\
\text { detected }\end{array}$ & $\begin{array}{c}\text { Not } \\
\text { detected }\end{array}$ & $\begin{array}{c}\text { Not } \\
\text { detected }\end{array}$ & $\begin{array}{c}\text { Not } \\
\text { detected }\end{array}$ & Not detected & Not allowed \\
\hline $\begin{array}{l}\text { L. monocytogenes } \\
\text { in } 25 \mathrm{~g}\end{array}$ & $1-42$ & $\begin{array}{c}\text { Not } \\
\text { detected }\end{array}$ & $\begin{array}{c}\text { Not } \\
\text { detected }\end{array}$ & $\begin{array}{c}\text { Not } \\
\text { detected }\end{array}$ & $\begin{array}{c}\text { Not } \\
\text { detected }\end{array}$ & Not detected & Not allowed \\
\hline Proteus in $0,1 \mathrm{~g}$ & $1-42$ & $\begin{array}{c}\text { Not } \\
\text { detected }\end{array}$ & $\begin{array}{c}\text { Not } \\
\text { detected }\end{array}$ & $\begin{array}{c}\text { Not } \\
\text { detected }\end{array}$ & $\begin{array}{c}\text { Not } \\
\text { detected }\end{array}$ & Not detected & Not allowed \\
\hline
\end{tabular}




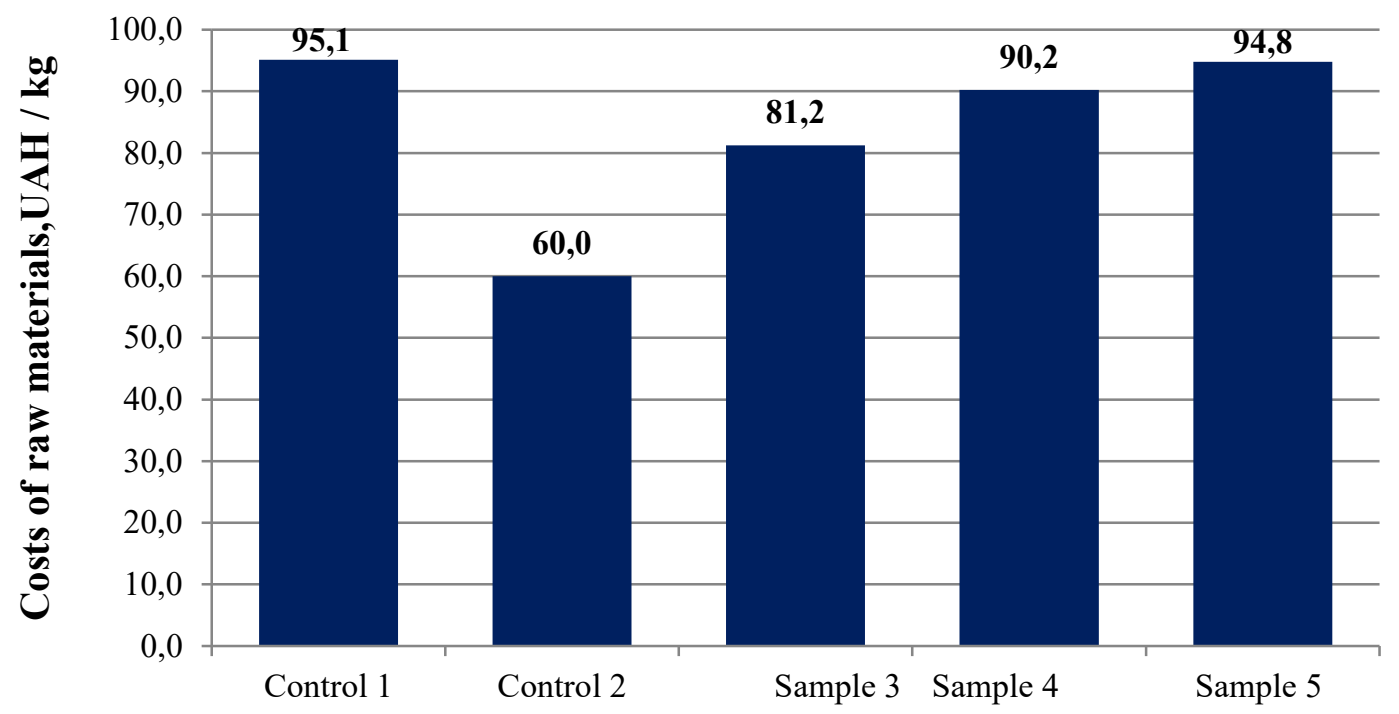

Fig. 1. Comparative assessment of raw material costs for the production of $1 \mathrm{~kg}$ of meat and fish semi-finished products

\section{BIBLIOGRAPHY}

1. Ситенко Р.О., Смірнова М.Т. Формування державної політики з охорони здоров’я в Україні. Вісник соиіальної гігієни та організації охорони здоров'я України. 2014. № 2 (60). С. 15-18.

2. Croix D.I., Gobbica P.E. Population density, fertility, and demographic convergence in developing countries. Journal of Development Economics. 2017. Vol. 127. P. 13-24. DOI: https://doi.org/10.1016/j.jdeveco.2017.02.003.

3. Population and fertility by age and sex for 195 countries and territories, 1950-2017: a systematic analysis for the Global Burden of Disease Study 2017. The Lancet. 2018. Vol. 392, Is. 10159. P. 1995-2051.

4. Patel J. et al. Oral health for healthy ageing. Personal View. 2021. Vol. 2. P. 521-527.

5. Leitea J.C., Caldeirac S., Watzld B., Wollgast J. Healthy low nitrogen footprint diets. Global Food Security. 2020. Vol. 24. P. 1-9. DOI: https://doi.org/10.1016/j.gfs.2019.100342.

6. Selvakumarasamy S., Rengaraju B., Adhiaman Arumugam S., Kulathooran R. Costus pictus - transition from a medicinal plant to functional food: A review. Future Foods. 2021. Vol. 4. P. 1-9. DOI: https://doi.org/10.1016/j. fufo.2021.100068.

7. Tsuchiya K. et al. Decentralization \& local food: Japan's regional Ecological Footprints indicate localized sustainability strategies. Cleaner Production. 2021. Vol. 292. P. 1-13. DOI: https://doi.org/10.1016/j.jclepro.2021.126043.

8. Аналіз асортименту i технологія виробництва січених напівфабрикатів. URL: https://dropt.ru/uk/smallbusiness/analiz-assortimenta-i-tehnologiya-proizvodstva rublenyh-polufabrikatov/ (дата звернення: 15.10.2021).

9. Статистична інформація : довідковий сайт по ЗЕД. URL: https://koloro.ua/ua/blog/issledovaniya/tendenciirazvitiya-rynka-myasnyhpolufabrikatov.html (дата звернення: 10.10.2020)

10. Пешук Л.В., Сімонова I.І. Розробка м'ясо-рибних формованих напівфабрикатів для геродієтичного харчування. Вісник Національного технічного університету «ХПI». 2021. № 3 (9). С. 74-80. doi:10.20998/2413-4295.20 21.03.11.

11. Influence of gerodietetic meat pate on metabolic parameters in the elderly: the role of vitamin $\mathrm{B}_{12} /$ Y.V. Gavalko, L.V. Peshuk, L.L. Sineok et al. Advances in gerontology Uspekhi gerontologii. 2015. № 28 (3). P. 571-578.

12. Здобнов А.И., Цыганенко В.А. Сборник рецептур блюд и кулинарных изделий : учебное пособие. Киев : Арий, 2013. 680 с.

13. Химический состав продуктов / под ред. И.М. Скурихина, М.Н. Волгарева. Москва : ВО «Агропромиздат», 1987. 224 с.

14. Dietary protein quality evaluation in human nutrition : Report of an FAO Expert Consultation. Rome : FAO, 2013. 66 p. URL: http://www.fao.org/3/a-i3124e.pdf

15. ГОСТ 30518-97. Межгосударственный стандарт. Продукты пищевые. Методы выявленния и определения количества бактерий группы кишечных палочек (колиформных бактерий). Межгосударственный совет по стандартизации, метрологии и сертификации. Действителен от 2001.07.01. Минск : Изд-во стандартов, 1997. 11 с.

16. ГОСТ 26972-86. Межгосударственный стандарт. Зерно, крупа, мука, толокно для продуктов детского питания. Методы микробиологического анализа. Действителен от 2003.05.01. Москва : Изд-во стандартов, 1987.14 с.

17. ДСТУ 8447:2015. Продукти харчові. Метод визначення дріжджів і плісневих грибів. Чинний від 2017. 07.01. Київ : ДП «УкрНДНЦ», 2016. 15 с. 


\section{REFERENCES}

1. Sytenko, R.O., \& Smirnova, M.T. (2014). Formuvannia derzhavnoi polityky z okhorony zdorovia v Ukraini [Formation of state policy on health care in Ukraine]. Formuvannia derzhavnoi polityky z okhorony zdorovia v UkrainiBulletin of social hygiene and health care organization of Ukraine, 2(60), pp. 15-18 [ in Ukrainian].

2. Croix, D.I., \& Gobbica, P.E. (2017). Population density, fertility, and demographic convergence in developing countries, Journal of Development Economics. 127. 13-24. doi: https://doi.org/10.1016/j.jdeveco.2017.02.003 [in English].

3. Population and fertility by age and sex for 195 countries and territories, 1950-2017: a systematic analysis for the Global Burden of Disease Study (2017). The Lancet, 392 (10159), 1995-2051. Retrieved from https://doi: 10.1016/ S0140-6736(18)32278-5 [in English].

4. Patel, J., Wallace J., Doshi M., Gadanya, M., Yahya, I.B., Roseman, J., \& et al. (2021). Oral health for healthy ageing, Personal View, 2, 521-527. [in English].

5. Leitea, J.C., Caldeirac, S., Watzld B., \& Wollgast, J. (2020). Healthy low nitrogen footprint diets, Global Food Security, 24, 1-9. doi: https://doi.org/10.1016/j.gfs.2019.100342 [in English].

6. Selvakumarasamy, S., Rengaraju, B., Adhiaman Arumugam, S. \& Kulathooran, R. (2021). Costus pictus - transition from a medicinal plant to functional food: A review. Future Foods, 4, 1-9. doi: https://doi.org/10.1016/j.fufo.2021.100068 [in English].

7. Tsuchiya, K., Katsunori, I., Murthy, A., Lin, D., Altiok, S., Rupprecht, D., \& et al. (2021). Decentralization \& local food: Japan's regional Ecological Footprints indicate localized sustainability strategies, Cleaner Production, 292, 1-13. doi: https://doi.org/10.1016/j.jclepro.2021.126043 [in English].

8. Analysis of the assortment and technology of production of numerous products. (2019). Retrived from https:// dropt.ru/uk/small-business/analiz-assortimenta-i-tehnologiya-proizvodstva-rublenyh-polufabrikatov/ [in Ukrainian].

9. Statistical information: pre-existing site for ZED. (2020). Retrived from https://koloro.ua/ua/blog/issledovaniya/ tendencii-razvitiya-rynka-myasnyhpolufabrikatov.html [in Ukranian].

10. Peshuk, L.V. \& Simonova, I.I. (2021). Rozrobka miaso-rybnykh formovanykh napivfabrykativ dlia herodiietychnoho kharchuvannia [Development of meat-ribbed molded napivfabrikativ for heroic food]. Visnyk Natsionalnoho tekhnichnoho universytetu "KhPI" - Bulletin of the NTU "KhPI". Series: New Solutions in Modern Technology, 3 (9), 74-80. doi: https://doi.org: 10.20998/2413-4295.2021.03.11 [ in Ukrainian].

11. Gavalko, Y.V., Peshuk, L.V., \& Sineok, L.L. (2015). Influence of gerodietetic meat pate on metabolic parameters in the elderly: the role of vitamin $\mathrm{B}_{12}$. Advances in gerontology, Uspekhi gerontologii, 28(3), 571-578 [in English].

12. Zdobnov, A.I., \& Tsyganenko, V.A. (2013). Sbornik receptur blyud i kulinarnyh izdelij : ucheb. posobye [Collection of recipes for dishes and culinary products: a tutorial]. Kiev: Ariy [in Russian].

13. Skurykhyn, Y.M., \& Volharev, M.N. (Eds) (1987) Khymycheskyi sostav produktov [Chemical composition of products] Moskow: VO "Ahropromyzdat" [in Russian].

14. Dietary protein quality evaluation in human nutrition : Report of an FAO Expert Consultation. Rome : FAO, 2013. 66. Retrieved from http://www.fao.org/3/a-i3124e.pdf [in English].

15. GOST 30518-97. Mezhgosudarstvennyj standart. Produkty pishevye. Metody vyyavlenniya i opredeleniya kolichestva bakterij gruppy kishechnyh palochek (koliformnyh bakterij). [Interstate standard. Food products. Methods for the identification and determination of the amount of bacteria of the group of Escherichia coli (coliform bacteria)]. (1997). GOST 30518-97 from 01 June 2001. Mezhhosudarstvennyi sovet po standartyzatsyy, metrolohyy y sertyfykatsyy. Mynsk: Yzd-vo standartov [in Russian].

16. 16 GOST 26972-86. Mezhgosudarstvennyj standart. Zerno, krupa, muka, tolokno dlya produktov detskogo pitaniya. Metody mikrobiologicheskogo analiza. [Interstate standard. Grain, cereals, flour, oatmeal for baby food. Microbiological analysis methods]. (1987). GOST 26972-86. from 01 May 2003. Moskow: Yzd-vo standartov [in Russian].

17. DSTU 8447:2015. Produkty kharchovi. Metod vyznachennia drizhdzhiv i plisenevykh hrybiv. [Food products. Method for determination of yeast and molds]. (2016). DSTU 8447:2015. from 01 June 2017. Kyiv: DP "UkrNDNTs" [in Ukrainian].

Л. В. Пешук, доктор сільськогосподарських наук, професор (Дніпровський національний університет імені Олеся Гончара); Г. В. Новік, кандидат технічних наук (Дніпровський національний університет імені Олеся Гончара); А. М. Савченко, І. П. Гончаренко (Дніпровський начіональний університет імені Олеся Гончара). Розробка нових видів м'ясо-рибних напівфабрикатів геродієтичного харчування.

Анотація. Здоров'я - ие унікальна цінність людства, тим паче у глобальну епоху пандемії COVID-19, тому поліпшення стану здоров'я населення - головне завдання суспільства, яке прагне до благополуччя та сталого розвитку. Харчова галузь критично значуща для людства та планети. Питання доиільності збалансованого харчування для забезпечення якості та подовження тривалості соиіально-активного життя набувае дедалі більшої актуальності майже в усіх краӥнах світу. Створення нових продуктів харчування зумовлено багатьма факторами: глобальними змінами клімату, що призводять до появи певних проблем у рослинництві та тваринництві, загальним погіршенням здоров'я людства, пов'язаним із новими технологіями вирощування, обробки та виробництва продуктів, що є передумовою винайдення профілактичних або лікувальних продуктів $і$ напоїв. М'ясна промисловість як найважливіша галузь національної економіки забезпечує населення країни одним із основних джерел білка. За багатовекторності ї̈ розвитку одним із важливих напрямів є виробництво замороженої продукиї̈, зокрема напівфабрикатів- 
м'ясних і м'ясомістких посічених. Незважаючи на нестабільну економічну ситуацію у країні та низьку купівельну спроможність населення, особливо людей похилого віку, серед головних чинників, які формують динаміку розвитку даного сегмента - поглиблення міжгалузевої кооперації, а саме у м'ясній промисловостірозширення асортименту заморожених напівфабрикатів.

3 огляду на вищевикладене своєчасним і перспективним напрямком є розробка рецептур і удосконалення технології виготовлення м'ясо-рибних напівфабрикатів із використанням м'ясної (філе індичого), рибної (хека), овочевої сировини та купажу олій (високоолеїнової соняшникової та олї̈ з виноградних кісточок). 3 а результатами досліджень було розроблено рецептури та розраховано харчову иінність нового продукту.

Ключові слова: м'ясо-рибний напівфабрикат, купаж олій, геродієтичне харчування, харчова ијінність. 